\title{
The Right to Food Sovereignty for Small Scale Farmers: Case Study of Farming Cooperatives in Limpopo Province, South Africa
}

\author{
Sharon Groenmeyer \\ Correspondence: Sharon Groenmeyer, Research Associate, The Centre for the Study of Democracy, University \\ of Johannesburg, Johannesburg, Gauteng, South Africa. E-mail: sgroenmeyer@uj.ac.za
}

Received: June 4, 2013 Accepted: June 21, 2013 Available online: July 15, 2013

doi:10.11114/ijsss.v1i2.180 URL: http://dx.doi.org/10.11114/ijsss.v1i2.180

\begin{abstract}
This paper on small scale farmers focuses on the right to food sovereignty in South Africa. Food sovereignty is defined as the fundamental democratic right to shape agricultural and food policy from the bottom up. Africa is the hardest hit by climate change because it depends on natural resources where small-scale agriculture is the dominant method of food production, except in South Africa where commercial agriculture dominates. This has direct links to climate change discourse reveals that rapid climate change including more frequent and intense weather systems with greater climate variability and the effects of increases in the average global temperature lead to changes in average rainfall patterns (Babagura 2011). In Sub-Saharan Africa, men make up approximately 85\% of landholders and women 15\% (UN Africa HDR 2012). Cultural practices and the dominance of patriarchal norms influence equal ownership and inheritance rights for men and women. Consequently landownership amongst women is lower in sub-Saharan Africa than in any other region in the world. In contrast, women make up approximately $50 \%$ of the agriculture workforce on male owned African small scale farms. Therefore, women in sub-Saharan Africa have less control than men do over productive resources such as assets of land and credit. Women's time is often devoted to the domestic sphere in activities that are non-marketed and undervalued and their access to key institutions such as markets is curtailed (Annecke 2010).

Climate change discourse demonstrates that the poor are disproportionately affected especially women who become shock absorbers during a food crisis, skipping meals to ensure family members have adequate nutrition. Household food security is part of a complex matrix of inequality which includes high levels of unemployment and increasing impoverishment because of the rising cost of basic services of electricity and water. Consequently, the increasing prices of basic foods like maize and wheat as the staple foods of most rural and urban poor poses a problem, because impoverished households are not buyers of food. Coupled with the stressors of poverty, poor health (HIV and AIDS) and societal inequalities (race and gender) small scale farmers have less flexibility to protect themselves or avoid risks.

This case study based on group interviews with small scale farmers who are members of cooperatives located in the Mopani District in the Limpopo Province in South Africa investigates how these small scale farmers have addressed food insecurity.
\end{abstract}

Keywords: feminisation of agriculture, cooperatives, small scale farming, food security, food sovereignty

\section{Introduction}

Ownership of land amongst women is lower in sub-Saharan Africa than in any other region in the world. While women make up approximately half of the agricultural workforce on male owned African small scale farms, the reality for women is that the lack of land ownership reproduces the existing inequalities of roles, positions and relations of power in that particular society, especially in South Africa. In Africa small scale farming is the dominant mode of food production and appears hardest hit by climate change because the majority of farmers depend on natural resources which are rapidly under attack by rising global temperatures. In South Africa commercial agriculture dominates the food production supply chain because the legacy bequeathed by the 1913 Natives' Land Act stripped Black farmers of their agricultural land. Consequently, the implementation of the Land Act evicted hundreds of Black sharecropper families from farms to live in the 'self-governing' Bantustans or recruited as cheap labour in the migrant labour system to work on the mines (Bundy 2013). Therefore the current 
South African agricultural context includes a dominant corporate - industrial structure in the agro-food system with a large-scale commercial agriculture producing at least $90 \%$ of marketed food in the country (Greenberg 2013).

More recently, policy makers have focussed on the importance of subsistence agriculture and its vital contribution towards fighting food insecurity and poverty (Baiphethi \& Jacobs 2009). This recognition has spurred small scale farmers, who are mainly Black members of farmer organisations, to plan and develop networks for the distribution of their produce. South Africa has an estimated 4,5 million small scale Black food producers, the vast majority are on land that is insufficient to produce enough food to feed their own households (Greenberg 2013). This resurgence of Black farmer associations is a symbol of hope for small scale farmers in the post-apartheid dispensation. An example is the small scale farmers organised into cooperatives in the Limpopo Province as a study in self-reliance towards a vision of food sovereignty.

While it is important to note that the link between food security and human development is not necessarily synonymous with economic growth, the literature indicates that poor nutrition could lead to illness and death if access to basic services - safe water, energy and sanitation are unavailable. The poor are disproportionately affected by climate change, especially women who are mothers who become shock absorbers during a food crisis, skipping meals to ensure family members are fed. This is because the poor do not have human or material resources to withstand financial shocks. Consequently, food sovereignty becomes a prerequisite for food security. Food production and good nutrition determines that food security sustains human development. Food security is defined as:

(the condition) when all people, at all times, have physical, social and economic access to sufficient, safe and nutritious food (to meet) their dietary needs and food preferences for an active and healthy life", (African Human Development Report 2012:9)

This paper leads from the proposition that the South African Constitution 1996 Bill of Rights Chapter 2 promotes democracy and equality and that this human rights approach permeates the national legislative framework. Therefore, a review of climate change protocols within the current democratising dispensation should echo this development paradigm. However, a review of the literature raises a recurrent question on the role of the South African government tin climate change policy formulation of national policy and adherence to international protocols. The next section conceptualises the research by building a framework on the intersection between food security, human development and gender. Section 3 highlights the subsistence nature of small scale farming which is rapidly becoming feminised. Section 4 incorporates a case study on small scale farmers who have formed co-operatives. The final section of the paper draws together the different debates on the South African government's approach to climate change and how this affects women's practical needs and strategic interests within a rapidly feminised small scale farming sector

\section{Methodology}

Using Miles and Huberman's (1994) approach, the paper constructs a conceptual framework to explain the key concepts of gender, small scale farmers who are members of cooperatives and how small scale farming has become feminised. This conceptual framework adopts an intersectional approach which enables the multiple complexities of perception of and/or experiences of social realities in a non-linear, contradictory and complex manner. In developing the conceptual framework three categories, namely food security, human development and gender are dissected in order to establish which category/ies of women and men experience the effects of climate change. The intersection of the three categories should reveal the ability of subjects (respondents who are African) to utilise the opportunities of equal citizenship as enshrined in the post-apartheid South African Constitution and Bill of Rights to construct or determine their own reality. Therefore, the conceptual framework unpacks the different strands of social relations that intersects with actual experiences, discourse and political agency across individual and institutional levels.

The conceptual framework is underpinned by a theoretical perspective on gender issues in agriculture. There are two popular theoretical approaches which acknowledge the feminisation of agriculture. The first approach, by FAO and the World Bank adopts a market based view of land, agriculture and gender (Gender CC: 2011).The second approach is held by Wichterich (2012) who supports a livelihood rights approach focussed on the concept of food sovereignty which is the approach adopted by this paper. According to the Food Sovereignty Network.

This is the right of people's to define their own food and agriculture; to protect and regulate domestic agricultural production and trade in order to achieve sustainable development objectives; to determine the extent to which they want to be self-reliant; to restrict the dumping of products in their markets; and to provide local fisheries-based communities the priority in managing the use of and the rights to aquatic resources. Food sovereignty does not negate trade, but rather, it promotes the formulation of 
trade policies and practices that serve the rights of peoples to safe, healthy and ecologically sustainable production. (Peoples Food Sovereignty Network 2002 cited in Patel, R (2009:666)

\subsection{Research Design}

In-depth interviews and focus group interviews using a semi structured interview schedule was developed. The qualitative research design uses participatory action research guided by stakeholder participation to strengthen activities and build the management capacity of the cooperative. The adoption of mixed qualitative methods facilitated the development of a case study to compare similarities, differences and anomalies of the various cooperatives which form part of this research process. The interviews were lead by the community development worker who through dialogue is able to share knowledge and experiences of small scale agricultural production.

Fourteen cooperatives with a total of 63 women and 45 men make up the study. Interviews were conducted with twelve crop and two mixed cooperatives (crops and livestock).

\begin{tabular}{|l|l|l|}
\hline Name of Cooperative & Municipality & Number of Participants \\
\hline SelwanePrieska & Ba-Phalaborwa & 5 members: 2 women and 3 men \\
\hline The Oaks Village Cooperative & Maruleng & 7 members: 6 women and 1 man \\
\hline Mzilela Cooperative, Dzumeri Farm Association & Greater Giyani & 16 women \\
\hline Mmamanyoha Vegetable/Poultry Cooperative & Greater Letaba & 9 women \\
\hline Jabulani and Phalaubeni, Hitekani Garden & Greater Giyani & 16 members: 13 women and 3 men \\
\hline Mbaula Cooperative & Greater Giyani & 48 members: 44 women and 4 men \\
\hline Lehlabile FA & Greater Tzaneen & 15 members: 7 women and 8 men \\
\hline Merekome FA & Greater Tzaneen & 38 members:11 women and 27 men \\
\hline Ramaruo Stock Farmers & Greater Tzaneen & 104 members: 43 women and 71 men \\
\hline Naka tsa Kgomo & Greater Tzaneen & 58 members: 14 women and 44 men \\
\hline Zava Women's Garden & Greater Giyani & 51 women only \\
\hline Sofaya Nursery Cooperatives & Maruleng & 7 members: 5 women and 2 men \\
\hline Tsa Hloka Seboka Cooperative & Maruleng & 12 members: 2 women and 10 men \\
\hline
\end{tabular}

The list of cooperatives interviewed.

The sample of cooperatives are located the municipalities of Ba-Phalaborwa, Maruleng, Greater Tzaneen, Letaba, and Greater Giyani in the Mopani District in the Limpopo Province. Various stakeholders including members of cooperatives, non-government organisation (NGO) staff and local government representatives were interviewed. Government policies, NGO documents and secondary academic literature on gender and food security were reviewed to substantiate the findings or to add new viewpoints to the research

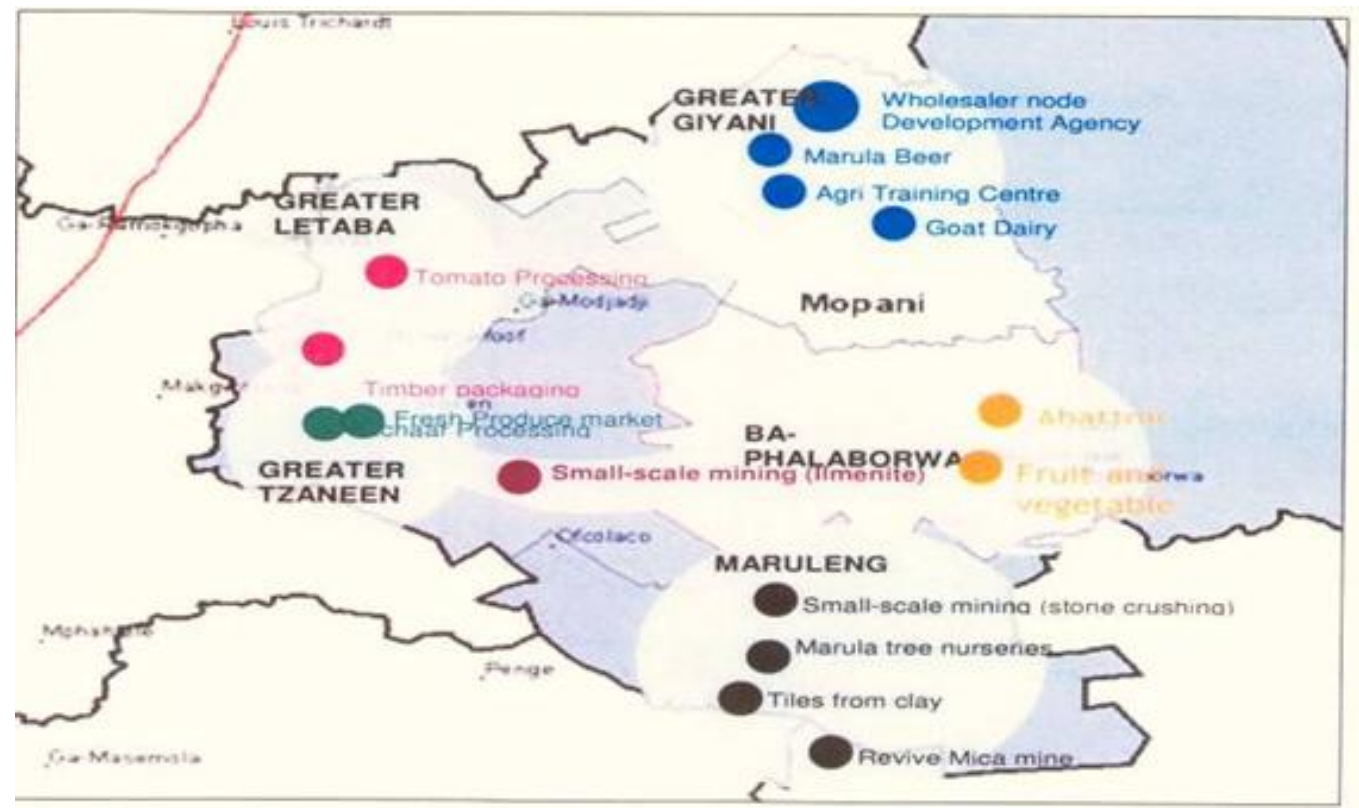

Map of Mopani District in Limpopo Province, South Africa 


\section{South Africa's Gendered Climate Change Policy}

South Africa has a strong foundation for human rights in its Constitution as signatories to international United Nations obligations such as the Committee on the Elimination of Discrimination against, Women (CEDAW),specific policies and laws, institutions that support democracy such as the Constitutional Court, the SA Human Rights Commission and the Public Protector (Govender 2012:14). South Africa's development discourse adheres to international protocols, especially the Bill of Rights Section 24 of the Constitution which stipulates that South Africa should have a clean healthy and safe environment. However, the introduction of more market oriented economic policies like the Growth, Employment and Redistribution (GEAR) macro-economic policy and more recently, the National Development Plan (2011) where the user pays for basic services conflicts with the human rights-oriented legislation promulgated to institute redress and correct apartheid's ills. South Africa's adherence to neoliberal policies facilitated the WTO General Agreement on Tariffs and Trade (1994) being implemented in a way that cost South Africa tens of 1000s of women's jobs (Govender 2012). This agreement opened the way for the privatisation and commodification of basic rights, including water, education and health care. Moreover, global corporations were allowed to exert undue influence on the policy priorities of many national governments. For example, the patenting of seed which global corporations believe the intellectual property is owned by them (Govender 2012).

Within the context of South Africa, the Department of Environmental Affair's White Paper (2011) correctly notes the potential impacts of unmitigated climate change will likely be catastrophic, including, droughts, extreme weather events, destruction of infrastructure, mass extinctions, the reversal of development gains and further impoverishment of people. Moreover, the paper recognises that South Africa is a water scarce country. While the South African government (WPNCRP: 2011)correctly notes that crop failures can therefore have a significant economic impact, a climate-resilient agricultural response depends on the recognition that agriculture should provide not only food, but also a range of other environmental and socio-economic benefits. Moreover, the appropriate use of small-scale labour-intensive agriculture techniques and models could reverse the present decrease in agricultural jobs; contribute to empowerment goals; promote food security; conserve soil quality and structure; and contribute to biodiversity. A critique of this paper is offered by Gender CC (2011:2) who note the White Paper is gender blind because it implies men and women have equal access to resources. More importantly, the paper does not recognise that there are power relations in gender, race and class inequalities and that emissions profiles between men and women is a subject of further study. Therefore, future studies should address the differences in emissions profiles and mitigative capacity between women and men (Lambrou and Pianna 2006). The authors further note that there is no conclusive body of evidence that the Clean Development Mechanism will specifically benefit economically disadvantaged women in developing countries. It is this confusion that underpins South African climate change protocols. (Earth Life Africa 2011).

In 2011, the UNFCC adopted a draft text on agriculture at COP 17 held in Durban South Africa. Agricultural organisations and specific countries supported the establishment of a separate work programme on agriculture which includes mitigation, adaptation, issues related to food security and technology transfer. While COP decisions can be found under the mitigation section, these decisions have not gone uncontested because several parties prioritise adaptation in the agricultural sector (Gender CC 2011:6). This is because under the mitigation track developed countries believe that adaptation could be neglected. A further concern is that a work programme focusing on mitigation would lead to new emission reduction obligations and that market based mechanisms would disadvantage small holder farmers. Consequently, there are a number of views on an agricultural work plan from both non-governmental organisations (NGOs) and government parties. La via Campesina has strongly rejected a work programme for agriculture and the extension of market mechanisms to include agriculture (Gender CC: 7). In contrast, South Africa is amongst the countries supporting a work programme with a greater focus on adaptation.

In response to the numerous discussions on agriculture at COP 17, the North American Co-ordinator for La via Campesina, Alberto Gomez comments on the Summary of the COP17 outcomes On Agriculture was that

\section{"The only way forward for agriculture is to support agro ecological solutions and to keep agriculture} out of the carbon market" (Khanya 2011)

Climate change continues to be a deeply political issue and economic justice for women, both as farm workers and small scale subsistence farmers cannot be achieved without considering climate change and sustainable development imperatives (Cock 2011). Therefore governments should be held accountable for exclusions and loss of sovereignty over natural resources. 


\section{Feminisation of Small Scale Agriculture}

In sub-Saharan Africa, men make up approximately $85 \%$ of landholders and women $15 \%$ (UN Africa HDR 2012).Cultural practices and the dominance of patriarchal norms dictate unequal ownership and inheritance rights for men over women. In South Africa, as in many countries in Africa, patriarchy is compounded by the coexistence of custom and statutory law. As Budlender and Alma (2011:39) note, each of these systems might work to the advantage or disadvantage of particular groups of women. Consequently, the coexistence of these two systems have deeply entrenched gender inequality, despite South Africa's progressive legislation. Therefore, women in sub-Saharan Africa have less control than men over productive resources such as assets like land and credit.

The legacy of the migrant labour system which lay the foundation for South Africa's industrialisation remains unaltered in this post-apartheid era because the high levels of rural unemployment force men to migrate while their wives remain in the former Bantustans. While the Land Act of 1913 was repealed in 1991 but continues to cast a shadow over post-apartheid South Africa because it created a fundamental legal distinction between reserves (Bantustans) and white-owned rural land (Bundy 2013). The South African policy, the Land Redistribution and Tenure Reform Programme aims to return at least $30 \%$ of land that was forcibly removed from Black people, or to provide those affected with financial compensation by 2014. Conceptually, the land, restitution and redistribution legs of the land reform policy were primarily concerned with asset ownership (FAO 2009). Therefore land reform has been an important aspect of post-apartheid South Africa. According to the Land Policy White Paper (South Africa, 1997), the mechanisms for land reform and its aims are supported by the South African Constitution which supports property rights. Land transactions occur in accordance with the 'willing buyer - willing seller' principle. This is because of the bifurcated nature of agriculture being either commercial farming which continues to be mainly white owned or small scale farming operated by emerging farmers who are mainly Black. Restitution targets both rural and urban land is an attempt to correct state interventions that occurred after the promulgation of the Land Act of 1913. The current land redistribution policy proposes transfer of ownership of land from white to Black farm-owners so that the Black ownership of land will become more widespread. Several years into the land and agrarian reform programme, the focus of programme implementation has narrowed from the transferring of land to poor people to transferring land for the purpose of providing beneficiaries with livelihoods based on the productive use of land.

Currently $8 \%$ of dispossessed land has been returned to its former owners. According to Abrahams, women formed 13, 3\% of beneficiaries of the claimants in 2004 (Abrahams 2009:4). According to the Commission on Gender Equality, men owned $92 \%$ of the land in 2005/2006 financial years. These figures have been marginally adjusted to $90 \%$ in 2009/2010. The land tenure reform leg of the policy aimed to enhance the rights of tenure security of vulnerable people, such as workers and their families residing on private land and people living in the former Bantustans. The main objective of the land tenure reform legislation is to clarify and strengthen the rights of people in relation to particular parcels of land with which they have been intimately associated for long periods of time but which they do not own. South African policymakers believe that legislation strengthening tenure rights can have a positive impact on farming and land use productivity. For example by making loans more accessible or to acquire production inputs for small scale farmers to capitalise their farms. The fact that land reform, tenure and security has not been tackled with the political will it deserves has meant that land reform has bumbled along.

While South Africa has a Ministry of Women, Children and Persons with Disabilities as well as having built gender sensitive institutions that protect women, the country is stubbornly patriarchal and the impending legislation of the Traditional Courts Bill will entrench 'traditional leaders' authority and make it increasingly difficult for women to challenge ownership of land, amongst other issues. As time has passed, the challenge related to entrenching substantive gender equality has become more apparent because South Africa's liberal democracy challenges any attempts at substantive gains for women. This may be challenging gendered inheritance laws in favour or women or rights to gender equality in a polygamous marriage. This means, that women must resort to costly legal avenues to entrench any gains in equality. These avenues are often closed to poor women. Often women's time is devoted to the domestic sphere in activities that are non-marketed, undervalued and their access to key institutions such as markets is curtailed. Budlender \& Brathaug (2000) notes the free labour of women is 247 minutes per day while men on average contribute 87 minutes on productive activities excluded from GDP calculation. Abrahams (2008:5) goes further to note that the value of unpaid labour could be calculated between $32 \%$ and $38 \%$ of GDP of which $75 \%$ is provided by women. It has further been estimated that $80 \%$ of unpaid labour in the agricultural sector is contributed by women (Weideman (2003: 9).Therefore the gender division of labour in farming is an important vehicle for understanding why women are 
considered responsible for securing nutrition with food and for ensuring food security. In contrast, cash crops and monetary income is considered the male domain. Because women work in the fields growing vegetables, fruit or flowers for export, as contract farmers or day workers, they are involved in the transnational systems of commercial agriculture and value chains (Witcherich 2012). However, women do not decide what happens to the products of their labour. This division of labour has implications for policy because the pursuit of productive use of land has become increasingly associated with engagement in market-oriented farming and related agri-business.

According to Baiphethi \& Jacobs (2009) the government of South Africa places particular importance on subsistence agriculture in its efforts to fight food insecurity and poverty. One of the objectives of the Integrated Food Security Strategy (IFSS) of the Department of Agriculture is to improve household food production, trade and distribution. This is to be achieved through:

- the development of policy interventions that target access to resources such as land, technology, credit and training;

- promotion of irrigation and rainwater harnessing technologies;

- improving access to credit by the poor, including women;

- improving access to food production and food processing technologies, particularly technologies for women;

- enhancing the ownership and exchange entitlement of the poor in the trade of agriculture and food sectors; and improving household food security by commercialising agriculture to increase income and employment generation among food-insecure households

(www.nda.agric.za/docs/Policy/FoodSecurityStrat.pdfwww.nda.agric.za/docs/Policy/FoodSecurityStrat.pdf)

Recently, national debates on the 'willing buyer willing seller' principle continue to rage amongst claimants. There are proposed amendments to the Restitution of Land Rights Act "which include amongst others is an opportunity for the re-opening of the lodgement of restitution claims, by people who missed the deadline of December 31, 1998" and for "exceptions to the June 1913 cut-off date, to accommodate claims by the descendants of the Khoi and San, as well as heritage sites and historical landmarks" (SAPA 2013).These are important considerations since the agricultural land in former homelands is over-utilized and poor quality. According to Budlender the Department of Labour estimated that 21,5m people live on some form of communal tribal land (Budlender 2011:9).According to the 2001 census 58,9\% were female living in tribal settlements (Budlender 2011: 9).

Baiphethi \& Jacobs (2009) research study on small scale farming has found that food gardens are popular among African women's groups in South Africa. The main aim of food gardens according to the respondents was to improve nutrition and create livelihoods. The production from small scale farming is part of land-based strategies as a safety net for households during times of need. Farmers practice smallholder diversified farming systems that provide most of the food consumed, and a substantial portion is cash crops. The more recent studies acknowledge the direct use value derived by households from land-based strategies, including small stock, goods and services associated with livestock produce from home gardens, wild or indigenous foods harvested from amongst staple crops, and the collection of natural resources for home consumption etc. (Shackleton et al, 2001).

Household food insecurity is complex because it cannot be seen in isolation from the high levels of unemployment and the steady increase in the cost of basic services such as electricity and water. Consequently, the increasing prices of basic foods like maize and wheat as the staple foods of most rural and urban poor poses a problem, because impoverished households are not buyers of food. The linkages between international, national and local commodity supply chains with economic networks highlight how producers collude to raise the cost of basic foods. Consequently, poor households spend larger proportions of income on food with a less diverse diet of low quality that provides less energy intake (Altman, Hart and Jacobs: 2009). Together with income inequalities, high levels of unemployment, skyrocketing inflation and depressed production levels because of the global financial crisis, the effects on women and vulnerable groups are severe (SADC Protocol 2012:342). More than one in four Africans are undernourished and food insecure. In South Africa, the National Food Consumption Survey (NFCS) of 2005 found that 52\% of households experience hunger (Labadarios et al. 2008).It further reports that another $33 \%$ of households are at risk of hunger, which means that food inflation and the loss of income might push them into hunger. Therefore the demand for food sovereignty by small scale farmers is because of the impact that rapid and intense changes to weather systems have on their crops (Babagura 2011, Witchterich 2012). The authors further note that where precipitation and seasons have become 
unpredictable, the cycles of sowing and harvesting are disrupted, which compromises agricultural production and food security and makes adaptation necessary (Witchterich 2012:19).

Small scale farmers understand that key resources (land, biodiversity and water) are essential for food sovereignty but they appear to operate outside the mainstream agricultural networks. During the period of the 1930-80s, the apartheid government heavily subsidised and supported large commercial agriculture, mainly white male farm owners. Post-apartheid agricultural policy no longer operates within this paradigm because large co-operatives have been privatised. Nor do the post-apartheid government policies provide support like subsidies, drought relief, credit, etc. for small scale farmers.).

Climate change and extreme weather patterns disrupt women's time management of the household when drinking water is contaminated by floods and they have to search for clean water. Climate change poses significant additional risks for water security, which in turn has knock-on effects for communities at risk of contracting water borne diseases. Current projections indicate that South Africa will exceed the limits of economically viable land-based water resources by 2050.The WPNCRP (2011:6) notes

'Although Government has provided basic water services to an estimated additional nine million people since 1994, they are mostly in urban areas. In many rural areas, lack of reticulated water and sanitation means that people rely on generally poorly managed local resources such as ground water, springs and rivers that are vulnerable to pollution and drought. Poor communities who are dependent on natural water resources cannot control the quality of their water or store the water supply in bulk.'

Therefore the rapidity of climate change affects food security which in turn has a direct influence on South Africa's attempt to meet MDG 1 of eradicating extreme hunger by 2014.

\section{Case Study of Small Scale Farmers in Limpopo Province}

Limpopo Province is located in a former Bantustan which for a century was a combination of over-population and failing subsistence agriculture. Even though the Land Act was repealed in 1991, the grinding poverty of the former Bantustans continue to cast a shadow over post-apartheid South Africa (Bundy 2013). Consequently, Limpopo is one of the poorest provinces in South Africa. The female population dominates with the sex ratio in Limpopo Province skewed in favour of women who are 52\% of the population. This is partly the historical legacy of apartheid legislation confining women to the former homelands eking out an existence by caring for the aged and children while men migrated to the cities to work on the mines. The high levels of malnutrition affect children who are experience stunting because of lack of adequate nutrition. Moreover child mortality remains low in Limpopo Province with 52 live births out of 1000. The statistics for survival beyond five years of age is equally dismal with 81 out of 1000 children (Bradshaw et al2004).

\subsection{The Research Process}

The interview questions were posed in English which the community development worker interpreted into Sesotho. Discussions on future production levels and building of distribution networks were eagerly embraced, especially entrepreneurial options for transport networks to the national fresh produce market located in Johannesburg. In some instances, women spoke of how produce could be sold to the local supermarkets. The discussion created moments of reflection on the current situation of subsistence farming and how certain crop levels could be increased towards building a more sustainable model of farming. The outcome of this process is the gathering of information on the planting cycling and production methods. Action research as a cyclical process feeds back directly into critical reflection of farming production in small scale farming thereby sharing information on the planning of the farming production process. The diagram below illustrates how participatory action research methods encourage members to take control of production technologies and make decisions about which crops to produce. Moreover, group discussions unlocked members' knowledge of the cultural specificity of certain production processes. Through dialogue or the action/reflection cycle, I gathered qualitative data that was common to the different cooperatives in this sample. 


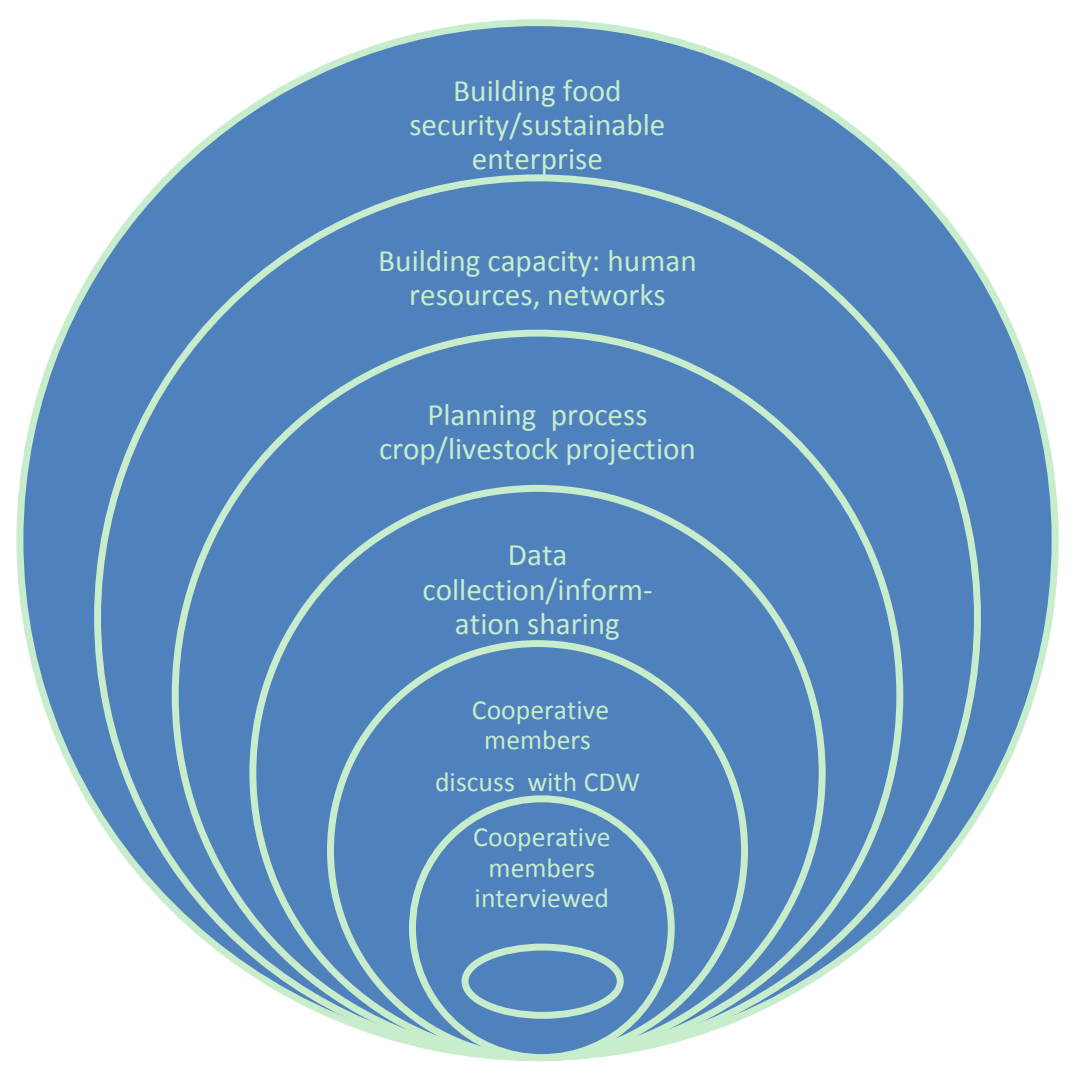

Description of the research process

The inhabitants of Limpopo Province are governed by the Traditional Leadership and Governance Framework (no 41 of 2003) which is mainly communal land. The land is not owned by the permit holder who has permission to till the plot. The research indicates that small scale farmers work plots range in size from 2-45 hectares. Men worked family plots while the majority of women worked in collective gardens

\begin{tabular}{|c|c|c|c|c|}
\hline \multicolumn{2}{|l|}{ Municipality } & \multicolumn{2}{|l|}{ Sex } & \multirow{3}{*}{$\begin{array}{l}\text { Total } \\
2\end{array}$} \\
\hline & & \multirow{2}{*}{$\begin{array}{l}\text { Male } \\
0\end{array}$} & \multirow{2}{*}{$\frac{\text { Female }}{2}$} & \\
\hline \multirow{3}{*}{ Ba-Phalaborwa } & family plot & & & \\
\hline & Collective garden & 3 & 0 & 3 \\
\hline & Total & 3 & 2 & 5 \\
\hline \multirow{3}{*}{ Maruleng } & family plot & 7 & 8 & 15 \\
\hline & Collective garden & 0 & 6 & 6 \\
\hline & Total & 7 & 14 & 21 \\
\hline \multirow{4}{*}{ Greater Tzaneen } & family plot & 16 & 3 & 19 \\
\hline & Collective garden & 3 & 3 & 6 \\
\hline & Backyard garden & 1 & 1 & 2 \\
\hline & Total & 20 & 7 & 27 \\
\hline \multirow{3}{*}{ Letaba } & family plot & 3 & 0 & 3 \\
\hline & Collective garden & 2 & 10 & 12 \\
\hline & Total & 5 & $\mathbf{1 0}$ & 15 \\
\hline \multirow{3}{*}{ Greater Giyani } & family plot & 7 & 0 & 7 \\
\hline & Collective garden & 3 & 30 & 33 \\
\hline & Total & 10 & 30 & 40 \\
\hline \multirow{4}{*}{ Total } & family plot & 33 & 13 & 46 \\
\hline & Collective garden & 11 & 49 & 60 \\
\hline & Backyard garden & 1 & 1 & 2 \\
\hline & Total & 45 & 63 & 108 \\
\hline
\end{tabular}

Farmholdings based on sex 


\subsection{Profile of Small Scale Farmers}

The average age of the farmers is between 51-60 years of age which is close to pensionable age in South Africa. Many farmers receive social grants which may include a disability, child support, foster child, care dependency, grant in aid, war veteran's or old age pension. The grants are used to purchase seeds, pay for transport or hire equipment for their plot. The lack of employment opportunities affects men and women differently. It would be fair to note that women continue to farm rather than seek wage employment because farming is a task that falls well within women's multiple roles and responsibilities in the household. Lack of employment opportunities in rural areas encourage men and youth to migrate to the city in search of work. Whereas, women's lack of mobility linked to their reproductive responsibilities continue to be one of the main reasons why women engage in farming of family plots or gardens. The research findings show that food produced by cooperatives is used mainly to supplement produce purchased during those times of the year when seasonal crops are not harvested. Therefore producing some food for the household increases food security, as well as releasing cash for other household uses. It also reduces reliance on cash to feed the household.

\begin{tabular}{|c|c|c|c|c|}
\hline \multicolumn{2}{|l|}{ Age } & \multicolumn{2}{|c|}{ Sex } & \multirow{3}{*}{\begin{tabular}{|l|} 
Total \\
6 \\
\end{tabular}} \\
\hline & & \multirow{2}{*}{\begin{tabular}{|l|} 
Male \\
2 \\
\end{tabular}} & \multirow{2}{*}{$\begin{array}{l}\text { Female } \\
4\end{array}$} & \\
\hline \multirow{3}{*}{ 20-30 years } & Greater Tzaneen & & & \\
\hline & Greater Giyani & \begin{tabular}{|l|l}
1 & $y$ \\
\end{tabular} & 2 & 3 \\
\hline & Total & 3 & 6 & 9 \\
\hline \multirow{6}{*}{$31-40$ years } & Ba-Phalaborwa & 1 & 0 & 1 \\
\hline & Maruleng & 5 & 9 & 14 \\
\hline & Greater Tzaneen & 2 & 1 & 3 \\
\hline & Letaba & 3 & 0 & 3 \\
\hline & Greater Giyani & 1 & 3 & 4 \\
\hline & Total & 12 & 13 & 25 \\
\hline \multirow{5}{*}{$41-50$ years } & Maruleng & 0 & 2 & 2 \\
\hline & Greater Tzaneen & 3 & 0 & 3 \\
\hline & Letaba & 0 & 2 & 2 \\
\hline & Greater Giyani & 0 & 5 & 5 \\
\hline & Total & 3 & 9 & 12 \\
\hline \multirow{6}{*}{$51-60$ years } & Ba-Phalaborwa & 1 & 0 & 1 \\
\hline & Maruleng & 0 & 3 & 3 \\
\hline & Greater Tzaneen & 8 & 1 & 9 \\
\hline & Letaba & 0 & 7 & 7 \\
\hline & Greater Giyani & 5 & 8 & 13 \\
\hline & Total & 14 & 19 & 33 \\
\hline \multirow{4}{*}{$61-70$ years } & Greater Tzaneen & 1 & 0 & 1 \\
\hline & Letaba & 2 & 1 & 3 \\
\hline & Greater Giyani & 2 & 9 & 11 \\
\hline & Total & 5 & 10 & 15 \\
\hline \multirow{6}{*}{ Total } & Ba-Phalaborwa & 2 & 0 & 2 \\
\hline & Maruleng & 5 & 14 & 19 \\
\hline & Greater Tzaneen & 16 & 6 & 22 \\
\hline & Letaba & 5 & 10 & 15 \\
\hline & Greater Giyani & 9 & 27 & 36 \\
\hline & Total & 37 & 57 & 94 \\
\hline
\end{tabular}

Age and Sex of small scalefarmers

Women walk long distances from their homes to work their plots and are easily recognisable in their brightly coloured dresses. During the interviews, women shelled the ground nuts or cleaned the pumpkin leaves in preparation for sale to the local community market. Children played amongst the pumpkin leaves while their mothers engaged in the discussions. Many women carried cell phones strung around their necks or in the aprons of their dresses. Because of the long distances between villages which are not electrified nor have basic infrastructure, the main form of communication or access to world outside their village is via cell phone technology. 
The female farmers and workers are not a homogenous group. Some women-only cooperatives employ local inhabitants and have been encouraged to enter local agricultural competitions and have won monetary prizes in 'the best emerging farmers' categories. The local municipality promote women and young people as 'emerging farmers' in the hope these farmers will invest their prize money in their farm either expanding or diversifying the produce. More importantly, these farmers are encouraged to generate employment for local inhabitants. Cooperatives with access to finance are able to expand their poultry or cattle produce which distinguishes these better resourced farmers from subsistence farming.

\subsection{Farming Methods and Impact of Climate Change}

The findings revealed that co-operative members work the land as a collective. The plot is divided into communal land and individual plots. The communal plot is harvested by the entire group. The proceeds from the sale of produce are used to manage the farm, like hiring tractors, improving the irrigation system or the purchase of seeds. Individual plots are worked by the owner of the plot. A number of women-only cooperatives are well known for their capacity to save the proceeds from the communal plot. The major vehicle for saving is the stokvel which is rotating credit system amongst a group of women. The profits derived from the communal plot are used for the hire of tractor, pay for electricity, purchase seeds, maintenance of the water pump or reservoir.

Working on one's individual plot is an incentive for each member to grow crops of their choice for consumption or for sale to the local market. The proceeds from the individual plots belong to the owner of the plot.

Co-operatives use indigenous knowledge systems of intercropping and eco-friendly planting systems which incorporate techniques ranging from using legumes for soil fertility to rainwater harvesting. However, local knowledge is gender specific based on men, women and youth access to resources and participation in decision making processes both in the home and at cooperative level. These practices encourage seed saving and crop diversity which are methods of safeguarding their production from shocks such as drought and maintaining the fertility and productivity of the soil (Mayet 2011:33).This shift to more eco-friendly farming methods, draws on 'traditional methods of farming' used by members' forefathers and mothers. The introduction of genetically modified seed creates a vicious cycle of confronting pests able to build resistance to eco-agricultural methods. As pointed out above, the productivity of subsistence production will be greatly increased by the use of improved inputs and technologies (seeds, fertilisers, water infrastructure, etc.). Moreover, improved access to water and appropriate farmer support (through extension services) will also have positive and significant impacts on improved yields for subsistence farmers. This will encourage farmer associations to stimulate a demand-driven approach to technology generation and information provision. Such farmer organisations are important in view of the huge shortcomings of agricultural extension services.

Some cooperatives have reliable irrigation systems pumping water from reservoirs while others rely on annual rainfall. Reliance on annual rainfall and unreliable irrigation systems are the main reasons for crop damage. With rapid climate change, co-operative members have noticed that the eco-agricultural methods are being compromised because rainfall patterns have changed. Climate change has altered the planting seasons destabilising the different eco-friendly methods of agriculture creating loss of produce for cooperatives using plant and animal manure as fertiliser. Increased temperatures encourage pests resistant to agro-ecological methods resulting in crop damage. Women told me that maize harvests used to be stored for ten years in the past but now the crops rot sooner because they are forced to plant genetically modified seed. In addition to harmful effects to the environment, the women cooperative members are aware of the harmful effects of chemicals on their health. Therefore, adaptation involving diversification of crops resilient to climatic change should be uppermost in the planning process for farmers.

Based on the conceptual framework of the feminisation of small scale farming, findings indicate that the sample of co-operatives in this study is mainly survivalist organisations. Translating the concept of food sovereignty into the South African context has been to identify gaps in the agro-food structure that would advance the concept materially (Greenberg 2013).According to Greenberg 'short chains' that connect producers to consumers in localised spaces like women selling vegetables and fruit from small stalls on the side of the road to the local community market. These localised spaces rooted in culturally specific values of mutual support and sharing create an exchange of knowledge and materials for production. Therefore women farmers' are major contributors of food to the local community market. Notwithstanding this fact, the local and provincial government departments do not acknowledged their contribution towards food security. This is demonstrated in their lack of support in terms of credit, farming implements, infrastructure development and distribution and marketing networks. Against the backdrop of increasing prices of food, subsistence production is important to improve 
household food security. This will reduce dependence on market purchases, especially among the rural poor, as they have the capacity (access to land) to exploit natural resources for food or to generate income.

\section{Conclusions}

This paper on small scale farming organised into cooperatives based in Limpopo Province, uses a livelihood rights approach focusing on the concept of food sovereignty where small scale farmers plan their own production outputs and determine the networks of trade in order to achieve sustainable development. Wiggins and Leturque (2010) note that smallholder development may be especially effective in reducing poverty since it tends to be intensive in labour, both of the family and also of neighbours who lack land and who are generally poor, thereby generating jobs and some income for those who need it. Therefore, the practical basis for the introduction of food sovereignty into the food system is to utilize the short chains that connect women cooperatives to the local community market which is mutually supportive and share or exchange knowledge and materials for production.

While, the principle of the right to food and human development is well-established among African governments, which have all ratified the UN protocols, for South Africa to realise MDG 3 on gender equality and MDG 1 of halving poverty by 2014, the feminisation of small scale farming has to be addressed. South Africa's commitment to human rights and gender equality is contradicted by government agreeing to a second round of the Kyoto Protocol which does not hold emitters accountable for their destruction to the eco-system. This duality is evident in the lack of coherence in policies promoting a low carbon economy, especially lack of enforcement and promotion of genetically modified seeds affecting livelihoods and food sovereignty thereby further entrenching gender inequality in society. In developing a conceptual framework on the feminisation of agriculture, small scale farmers, especially women must move as bell hooks notes (2000) from the margins to the centre as active agents who alter the power relations at home, community and society in general.

\section{Acknowledgements}

I would like to acknowledge the assistance of the Itirileng Development Education Project IDEP) staff, especially Matome Malaji , Mokgadi Pilusa, Kedibone Shai, the members of the Mopani Farmers Union, Limpopo Province and the IDEP community development workers.

\section{References}

Abrahams, Y. (2009). Plaiting three strands: Gender based violence as a cause of global warming. DAC/HSRC Colloquium on Social Cohesion 2009.

Adam, F. (2011). South Africa's role in the climate crisis in Khanya College Journal no. 29. December 2011. Pages 29-31

African Human Development Report. (2012). Towards a food secure future. United Nations Development Programme, USA

Altman, M., Hart, T. G. B., \& Jacobs, P. T. (2009). Household food security status in South Africa in Agrekon, 48(4).

Asenso-Okyere, K., \& Jemaneh, S. (2012). Increasing Agricultural Productivity \& Enhancing Food Security In Africa New Challenges \& Opportunities Synopsis Of An International Conference. International Food Policy Research Institute. Washington, DC. March 2012.

Babugura, A. (2010). Gender and Climate Change: South Africa Case Study. Heinrich Boll Stiftung. Heinrich Boll Foundation Southern Africa.

Bailey, R. (2011). Growing a Better Future Food justice in a resource-constrained world. www.oxfam.org/grow accessed 23October2012.

Baiphethi., \& Jacob, P. T. (2009). Increasing Agricultural Productivity \& Enhancing Food Security in Africa. Agrekon, 48(4).

Bradshaw, D., Nannan, N., Laubscher, R., Groenewald, P., Joubert, J., Nojilana, B., Norman, R., Pieterse, D., \& Schneider, M. (2004). South African National Burden of Disease Study 2000 - Estimates of Provincial Mortality. Cape Town: South African Medical Research Council, Burden of Disease Unit. http://www.ci.org.za/depts/ci/pubs/pdf/general/gauge2008/part_three/childhealth.pdf.accessed 4 October 2012

Budlender, D., \& Alma, E. (2011). Women and Land. Securing Rights for better lives. International Development Research Centre, Canada. 
Budlender, D., \& Brathaug, A. (2002). Calculating the Value of Unpaid Labour: A Discussion Document Statistics South Africa Working paper 2002/1, 2002, 15.

Bundy, C. (2013). Centenary of the 1913 Land Act in Amandla, 30(April/May), 25-27.

Care. (2012). Into Unknown Territory: The limits to adaptation and reality of loss and damage from climate impacts. http://www.careclimatechange.org/files/CARE_docs/2012_Into\%20Unknown\%20Territory_Joint\%20Report.p df accessed 27 September 2012

Cock, J. (2011). The relation between climate change and food security. Khanya College Journal, 29, 31-33.

Commission on Gender Equality. (2011). Ten stumbling blocks that hinder women empowerment in South Africa. Johannesburg.

Constitution of the Republic of South Africa Act No 108 of 1996. www.info.gov.za/documents/constitution/1996/a108-96.pdf

Cousins, B. (2012). Agricultural policy and the right to food in South Africa. May 2012, UCT pdf accessed 23 October 2012.

Department of Environmental Affair's White Paper on National Climate Change Response Paper. (2011). www.environment.gov.za/.../national_climatechange_responseaccessed 23 October 2012

Earth Life Africa comment on SA White Paper on Climate Change Response paper accessed http://www.earthlife.org.za/wordpress/wp-content/uploads/2011/10/ELA-Jhb-White-Paper-Comments-21oc t2011-FINAL1.pdf

Fakir, S. (2011). The failings of climate negotiations. Khanya College Journal, 29, 5-7.

FAO. (2009). A review of experiences of establishing emerging farmers in South Africa: Case lessons and implications for farmer support. ISSN 1729 17729-8199. Prepared by Umhlaba in association with: ARDRI and Phuhlisami.

Gender, C. C. (2011). Briefing paper on UNFCC and Agriculture. Berlin. www.gendercc.net

Genderlinks. (2012). SADC Gender Protocol 2012 Barometer. Genderlinks. Johannesburg.

Govender, P. (2012). SA's Democracy and Human Rights: Progress and Challenges, at the second Annual Public Lecture. Second Annual Public Lecture delivered at University of Witwatersrand on 3 October 2012. www.politicsweb.co.za/politicsweb/view/...en/page71656? Accessed 7 October 2012

Green Paper on Land Reform in South Africa. www.info.gov.za/view/DownloadFileAction?id=150833accessed on 23 July 2012

Greenberg, S. (2013). Industrial agriculture vs food sovereignty in Amandla, 30(April/May), 28-29.

Groenmeyer, S. (2012). Baseline study of cooperatives in Mopani District in Limpopo Province. Unpublished document.

Hooks, B. (2000). Feminist Theory - From Margin to Centre, 2nd edition, South End Press, Cambridge, MA.

Hooks, B. (2000). Feminist Theory - From Margin to Centre, $2^{\text {nd }}$ edition, South End Press, Cambridge, MA.

Integrated Food Strategy for South Africa. (2012). Department of Agriculture. www.nda.agric.za/docs/Policy/FoodSecurityStrat.pdf accessed 24 June 2013

Jones, G. (2012). GMOs have made no impact on food security in South Africa in fourteen years. ACB responds to DA position. Monday, 10 September 2012 www.biosafetyafrica.org.za accessed 24 October 2012

Khanya College. (2011). Climate change issue, 29. Johannesburg.

Labadarios, D., Swart, R., Maunder, E. M. W., Kruger, H. S., Gericke, G. J., Kuzwayo, P. M. N. et al. (2008). 'Executive summary of the National Food Consumption Survey: Fortification baseline. (NFCS-FB-1)', South African Journal of Clinical Nutrition 21(3) (suppl. 2), 247-300.

Lambrou, Y., \& Piana, G. (2006). Gender: The missing component of the response to climate change. Paper or Gender and Population Division Sustainable Development Department.Food and Agriculture Organization of the United Nations. April 2006.

Land Policy White Paper. (South Africa, 1997). Restitution of Land Rights Act 22 of 1994 - South Africa Government. www.info.gov.za/acts/1994/a22-94.pdf accessed 23 July 2012 
Marais, H. (2011). Closing the Poverty Gap: An income grant beats job creation. The Cape Time, October 5, 2011. P.11.

Mayet, M. (2011). SA government's promotion of genetically modified agriculture undermines farming and food security in South Africa and Africa. Khanya Journal, 29.

Miles, M. B., \& Huberman, A. M. (1994). Qualitative Analysis: an expanded sourcebook, Sage Publications, London.

Oxfam. (2011). Growing a Better Future. London. www.oxfam.org/grow accessed 28 October 2012

Patel, R. (2009). Food sovereignty. The Journal of Peasant Studies, 36(3), 663-706.

SA Government White Papers on Land Reform. (1997). www.polity.org.za/polity/govdocs/white_papers accessed on 23 July 2012

SAPA. (2013). 'Willing buyer, willing seller' principal to go: Zuma' from the Independent Online, 14 February, [online], Available www.iol.co.za[Accessed 25 June 2013].

Scampini, A. (2012). Rural Women and Food Sovereignty.AWID. www.Awid.org accessed 28 October 2012.

Shackleton, C. M., Shackleton, S. E., \& Cousins, B. (2001). The role of land-based strategies in rural livelihoods: The contribution of arable production, animal husbandry and natural resource harvesting in communal areas in South Africa. Development Southern Africa, 18, 581-603.

Terry, G. (2009). No climate justice without gender justice: an overview of the issues. Gender \& Development, 17(1), 5-18.

Weideman, M. (2003). Women and Land Reform in South Africa. Accessed 22 November 2012.

Wiggins, S., \& Leturque, H. (2010). Helping Africa to FeedItself: PromotingAgriculture to ReducePoverty and Hunger. January 2010. Occasional Paper 002.www.future-agricultures.org accessed 28 October 2012.

Witcherich, C. (2012). The Future We Want - A Feminist Perspective. Volume 21 (English edition). in the Publication Series on Ecology Edited by the Heinrich Böll Foundation 2012.

\section{(cc) Br}

This work is licensed under a Creative Commons Attribution 3.0 License. 